\title{
THE DETERMINATION OF FINANCIAL STRUCTURE IN AGRICULTURE, FORESTRY AND FISHING INDUSTRY IN SELECTED COUNTRIES OF CENTRAL AND EASTERN EUROPE
}

\section{Petra Růčková1, Nicole Škuláňová2}

\footnotetext{
1 Silesian University in Opava, School of Business Administration in Karviná, Department of Finance and Accounting, Czech Republic, ORCID: 0000-0001-8558-6212, ruckova@opf.slu.cz;

2 Silesian University in Opava, School of Business Administration in Karviná, Department of Finance and Accounting, Czech Republic, ORCID: 0000-0003-3715-0988, skulanova@opf.slu.cz.
}

\begin{abstract}
Every economic sector, every single industry, every economy, and even every firm has its specific financial structure. Given that it is not possible to examine thousands of individual companies for scientific purposes, it is necessary to at least examine the differences between individual sectors, industries and countries. At the same time, the formation and optimization of the financial structure is influenced by a myriad of diverse factors that financial managers should take into account in their decisions. Thanks to these facts, more and more researches had been created for over half a century. This research expands knowledge in seven selected countries of Central and Eastern Europe - the Visegrád Group, Bulgaria, Slovenia and Romania. The aim of the research is to evaluate, based on the Generalized Method of Moments, the relationship between the six selected factors and the indebtedness level in companies belonging to the agricultural, forestry and fishing industry. The subject of the research is medium, large and very large companies during the years 2009 to 2016. The research deals with the influence of profitability, liquidity, asset structure, economic development, inflation and interest rates on the total, long-term and short-term indebtedness of companies. The main finding of the research is that companies are influenced by both internal and external determinants. However, even though the industry should be neutral, external determinants - GDP growth rates, inflation rates and interest rates - have a more significant impact on the debt level. The results of this research will not only extend current knowledge in the field of corporate finance, but at the same time, the results may be stimulating in setting support rules for public administration and even European institutions, as the selected industry is strongly linked to subsidy policies.
\end{abstract}

Keywords: Financial structure, profitability, liquidity, non-debt tax shield, asset structure, GDP, inflation, interest rate.

JEL Classification: G32.

APA Style Citation: Růčková, P., \& Škuláňová, N. (2021). The Determination of Financial Structure in Agriculture, Forestry and Fishing Industry in Selected Countries of Central and Eastern Europe. E\&M Economics and Management, 24(3), 58-78. https://doi.org/10.15240/ tul/001/2021-03-004

\section{Introduction}

Every company needs financial resources for its business activities before its establishment and during its existence. For accounting purposes, these funds are arranged in the balance sheet, in which they form a part called the capital or 
financial structure, which, including both longterm and short-term sources of funding, is the subject of this research. In addition to the time structure, the financial structure is further divided into equity and debt sources of financing. The question that economists have been trying to answer for more than half a century is "what the right ratio of equity and debt sources of funding is?" We could find studies of various years, such as Modigliani and Miller (1963), Bradley et al. (1984), Bokpin (2009), Orlova et al. (2020), Růčková and Stavárek (2020) or Jin (2021). Unfortunately, even in such a long time, no answer has been found, because the balance of funding sources is influenced by a number of factors and therefore, countless studies dealing with this issue are still being published. In view of this fact, there is no general theory of capital structure, as stated by Myers (2001). Given the number of known and even unknown factors, it is important to continue to pay attention to this area and examine other samples of companies from various countries and industries. Indeed, previous researches show that the results vary widely due to the size of the companies, the industry, the country and the sample size.

All these facts became a motivation to provide this research considering agriculture, forestry and fishing industry in seven selected countries of Central and Eastern Europe. Knowledge in the field of capital/financial structure to be disseminated to given economies should become the main benefit of this research as those countries are not so often examined. The dissemination of knowledge lies in the fact that the selected countries are examined individually from the perspective of given industry, which is not a matter of course as the authors often create one panel composed of different countries, results of which cannot be applied to all countries in the sample. This procedure can be found, for example, in Klapper et al. (2002), Hernádi and Ormos (2010), Jõeveer (2013), and Mateev et al. (2012). At the same time, the selected industry is very often not the subject of research. Three studies have been found, which are connected to a selected sector - Prášilová (2012), Aulová and Hlavsa (2013), Sikveland and Zhang (2020). Companies are also divided by size into medium and large ones bringing thus a positive aspect to the research as the different impacts of determinants can be possibly seen. Last but not least, this research examines a large sample of companies, in total 10,644 of them. It must be said that unfortunately not all companies are taken from the database as some companies had zero or undisclosed data. Finally, this research should describe the behaviour of companies in the industry in each economy. And therefore, the results of this research may be stimulating in setting support rules for public administration and even European institutions, as the selected industry is strongly linked to subsidy policies.

In a historical point of view, as written above, this issue has been discussed for over half a century. The basic and initial study of this area is considered to be "The Cost of Capital, Corporation Finance and the Theory of Investment" of 1958 by Modigliani and Miller. Two basic theories of capital structure emerged out of this study - trade-off theory and pecking order theory. Brealey et al. (2011) and trade-off theory seek the optimum of capital structure through a balance between the tax advantage of debt and the cost of financial distress. Myers (1984) and pecking order theory create a hierarchy of funding sources with the conclusion that equity should be preferred to debt. Many other studies were based on these two theories, and virtually all researches reflection, builds on, and expands on these three researches Modigliani and Miller (1958), Myers (1984), and Brealey et al. (2011). As the number of studies has grown, the number of known determinants, countries and industries has grown as well.

This paper is organized as follows. Section 1 defines earlier researches on the financial structure and selected determinants suggested by this study. Section 2 presents the research methodology, data, and variables and provides with the characterization of industry and examined economies. Section 3 describes the results of the analysis of variable dependencies using panel regression. Section 4 presents the conclusions.

\section{Literature Overview}

As already indicated in the introduction, the formation and optimization of the company financial structure is quite a demanding activity due to the number of factors influencing the decisions made by the financial managers. Usually, these determinants are divided into those given by company's internal environment and those coming from the external environment. Both of these groups are 
represented in this research. Intra-company determinants are represented by company profitability, liquidity and asset structure. Noncorporate determinants are represented by the development of the GDP growth rate, the inflation rate and the level of the basic interest rate of the given economy. The following section will gradually mention the assumptions related to each factor as well as previous studies dealing with them. Before the literature overview, it should be mentioned that all determinants can have a positive and negative impact on the debt level.

The positive impact of profitability on the indebtedness level is promoted by the tradeoff theory (Brealey et al., 2011), which says that if companies are more profitable, their financial distress costs decrease reducing the likelihood of bankruptcy and making companies suitable for granting a loan. This relation has been confirmed by, e.g., Klapper et al. (2002), Pinková (2012), Aulová and Hlavsa (2013) for agricultural enterprises and Mokhova and Zinecker (2013) in Slovenia. On the contrary, the negative impact of profitability is supported by pecking order theory (Myers, 1984) saying that as profits grow, so do other parts of it such as retained earnings, which are a very cheap means of financing. This link is far more common in previous researches. The negative link also prevails when debts are divided into total, long-term and short-term ones. This relation was noted, for example, by Nivorozhkin (2005), Weill (2004), Črnigoj and Mramor (2009), Hernádi and Ormos (2010), Hanousek and Shamshur (2011), Mateev et al. (2012), Mokhova and Zinecker (2013), Prędkiewicz and Prędkiewicz (2015), Růčková (2015b) for Poland and Slovakia, Hang et al. (2018), Yildirim et al. (2018), Bilgin (2019), Moradi and Paulet (2019), Orlova et al. (2020), Touil and Mamoghli (2020), Sikveland and Zhang (2020), and Jin (2021).

The positive relationship between liquidity and indebtedness is explained by the fact that if the company is hit by an unfavourable situation, it can sell highly liquid assets and thus survive the bad period. However, in order to sell such assets, it should possess of some amount of such assets for such a case. Illiquid assets are difficult to sell and their sale is loss-making. These assets usually include fixed assets. The truths should apply that liquid assets are financed by debt, illiquid by equity. This relation is supported by the results of, e.g., Mateev et al. (2012) as for long-term debt, Růčková (2015b) in the Czech Republic, Ramli et al. (2019) for Indonesia. A negative impact can be caused by a potential conflict between managers and owners; if managers could freely dispose of the company's assets, they could expropriate the owners by gradual sale. This relationship is supported by Lipson and Mortal (2009), Mateev et al. (2012) for short-term debt, Pinková (2012), Aulová and Hlavsa (2013), Růčková (2015b) in Poland and Slovakia, Bilgin (2019), Ramli et al. (2019) for Malaysia.

The structure of assets has an impact on debt according to its composition. A positive link is expected for long-term debt and a negative one is expected for short-term debt. These expectations have been revealed by, e.g., Mateev et al. (2012), Prášilová (2012), Mokhova and Zinecker (2013) in Bulgaria, Hungary and Slovenia, Hang et al. (2018), Sikveland and Zhang (2020). These expectations are given by a variable representing this determinant. Usually it is the ratio of tangible and total assets. Tangible assets are fixed assets that can be used as collateral when applying for a loan. However, there are several pitfalls that disrupt these expected links. The first one, the orientation of the given economy financial system is as these links apply only in a bank-oriented system as the pledge cannot be used on the financial markets, as stated by, e.g., Acedo-Ramirez and Ruiz-Cabestre (2014). The size of the company is the second difficulty because a large number of tangible assets should be available to medium-sized and especially large companies as stated by Klapper et al. (2002), Daskalakis et al. (2017) and Lourenço and Oliveira (2017). The last problem is the industry under study; industries with a large amount of stocks, such as agriculture, cannot use stocks as collateral as confirmed by the results of, e.g., Aulová and Hlavsa (2013) and Růčková (2015a).

The positive impact of economic development on the indebtedness level can be explained by the fact that if the economy thrives, corporate profits usually increase, and in this case, we return to the explanation as in profitability through trade-off theory. This link was confirmed by, e.g., Gajurel (2006) for long-term debt, Hanousek and Shamshur (2011) for unlisted companies, Yinusa et al. (2017) for long-term debt, Ramli et al. (2019) for Indonesia. On the other hand, when the 
economy is thriving and profits are growing, pecking order theory can also be applied and a negative link can be assumed. This link can be found, for example, in Gajurel (2006) for total and short-term debt, Cheng and Shiu (2007), Bokpin (2009), Hanousek and Shamshur (2011) for listed companies, Jõeveer (2013) for unlisted companies, Yildirim et al. (2018), Ramli et al. (2019) for Malaysia.

The negative relationship between the inflation rate and the debt ratio is assumed for long-term debt, as the inflation rate should reduce the already existing debt together with the decline in the real interest rate. This relationship can be found, for example, in Gajurel (2006) as for total indebtedness, Jõeveer (2013), Öztekin (2015), Daskalakis et al. (2017), Bilgin (2019). A positive relationship between the inflation rate and debt is expected only for short-term debt. This expectation is based on the fact that when lowering the real interest rate, creditors can hedge themselves by e.g. linking the interest rate to inflation. However, it is possible to secure it in only the short-term period. This relationship can be found, for example, in Hanousek and Shamshur (2011), Yinusa et al. (2017), Ramli et al. (2019).

The basic interest rate is the last variable. In this case, the impact on the debt level is expected according to the maturity of the economy. The assumption is that developed countries will show a positive bond and developing countries will show a negative bond. This fact is influenced by the difference between these countries in terms of the quality of institutional, legal and regulatory environment as reported by Yinusa et al. (2017).

As it comes to the external factors, it should be mentioned that a number of studies found some link, which was unfortunately not statistically significant. Therefore, it is very important to include these factors regularly in studies in order to obtain as many statistically significant results as possible.

\section{Data and Methodology}

The subject of this research, companies classified according to the NACE classification in section A - Agriculture, forestry and fishing are. The input time series come from the Orbis and World Bank databases. A total of 10,644 companies were analyzed, of which 9,771 are medium-sized and 873 are large and very large companies. Unfortunately, these are not all companies of the Orbis database as some companies lacked some data or there were often zero data found thus these companies were excluded. The analysis of sub-industries showed that in almost all economies the subindustry Crop and animal production, hunting and related service activities dominates, in which $85 \%$ of medium-sized companies and $65 \%$ of large companies from the total sample examined operate. However, in panel regression analyses all these sub-industries together for each country, as in some economies there is only one or no company, and therefore it would not be possible to examine the determinants of the impact on the financial structure. Research seeks to compare the whole industry regardless of its individual parts. The analysis of the companies includes the period from 2009 to 2016.

Regarding the analyzed economies, seven economies of Central and Eastern Europe were selected - the Czech Republic (CZ), Slovakia $(\mathrm{SK})$, Poland (PL), Hungary (HU), Slovenia (SI), Bulgaria (BG), and Romania (RO). This is an extended Visegrád Group, which often includes Austria, but in this industry, almost all companies have not disclosed profit values, which is an important part of the calculations and of the analysis itself. Slovenia, Bulgaria, Romania and Austria are very often associated with the V4, as representatives of these countries attend various meetings of this group and cooperate with it. Those countries were chosen due to the lack of studies considering them and the industry.

The aim of the research is to evaluate, based on the Generalized Method of Moments, the relationship between the six selected factors and the indebtedness level in companies belonging to the agricultural, forestry and fishing industry. The research is provided at three levels according to the period, in which funding sources are used. The first level, the use of total debt resources is, the second level includes long-term debt resources and the third one considers the use of short-term debt resources.

With regard to the formulated aim and literature overview, two research questions are formulated:

1. Are there differences in impact over different maturities of use of the funding sources used?

2. Does the price of financial external sources affect the use of them? 
Tab. 1: Expected relationships between selected factors and indebtedness level

\begin{tabular}{l|c|c|c} 
& Total debt & Long-term debt & Short-term debt \\
\hline Profitability/liquidity & - & - & - \\
\hline Liquidity & - & - & - \\
\hline Asset structure & - & + & - \\
\hline Inflation & - & - & + \\
\hline GDP growth rate & + & + & - \\
\hline Interest rate - CZ, SK, SI & + & + & + \\
\hline Interest rate - PL, HU, RO, BG & - & - & - \\
\hline
\end{tabular}

Tab. 1 shows the assumed links based on a literature overview. To assume the impact of the interest rate on the indebtedness level, countries were divided according to the degree of economic development into developed and developing economies as stated in the literature overview. The division is based on the division by the IMF - World Economic Outlook October 2020.

\subsection{Variables}

In the empirical part, three models for three forms of indebtedness are created within the panel regression, and thus indebtedness acts as an endogenous variable. The variable also takes three forms - the ratio of total liabilities to equity (DER), the ratio of long-term liabilities to equity (DER_L) and the ratio of short-term liabilities to equity (DER_S). The following distribution of the endogenous variable can be found, for example, in Pinková (2012), Mokhova and Zinecker $(2013,2014)$, Sikveland and Zhang (2020).

Furthermore, there are six exogenous variables in each model representing selected determinants of the financial structure. Of course, the factors that affect the capital structure are innumerable. Factors that are clearly related to debt sources obtaining were selected for this research. Companies have to reach a certain level of profitability in order for someone to lend them. At the same time, it is usually required to have a certain amount of highly liquid assets in the event of immediate repayment of liabilities, and companies should also have a certain amount of tangible assets that can be used as collateral to raise external resources. The development of the economy is related to the willingness of potential creditors. The interest rate and the inflation rate are linked to the cost of debt financing. However, factors were also selected on the basis of frequency in previous studies, as some factors are abundant, but for some of them, there is no larger number of studies with mainly statistically significant results.

Specific factors include the share of EBIT and total assets (ROA). This determinant is present in almost every study dealing with this issue, e.g., Prášilová (2012), Aulová and Hlavsa (2013), Hang et al. (2018), Yildirim et al. (2018), Bilgin (2019), Moradi and Paulet (2019), Orlova et al. (2020), Touil and Mamoghli (2020), Sikveland and Zhang (2020), Jin (2021). Liquidity, in our case quick ratio (L2), can be found, for example, in the studies of Mateev et al. (2012), Pinková (2012), Aulová and Hlavsa (2013), Růčková (2015b), Bilgin (2019), Ramli et al. (2019). The asset structure as the share of tangible assets and total assets (SA) is also a very numerous factor. It can be found, for example, in Prášilová (2012), Aulová and Hlavsa (2013), Mokhova and Zinecker (2013), Daskalakis et al. (2017), Hang et al. (2018), Lambrinoudakis et al. (2019), Sikveland and Zhang (2020), Jin (2021).

The last three determinants represent the external environment of the company. Although these factors are present in previous studies, there is not a large number of studies with statistically significant results. The GDP growth rate can be found in the studies of Hanousek and Shamshur (2011), Jõeveer (2013), Yinusa et al. (2017), Yildirim et al. (2018), Ramli et al. (2019). The inflation rate (INF) was examined, for example, by Öztekin (2015), Yinusa et al. 
(2017), Huong (2018), Daskalakis et al. (2017), Bilgin (2019), Ramli et al. (2019). Dependency between leverage and the basic interest rate of the economy (IR) we can find in the studies of Bokpin (2009), Yinusa et al. (2017), Daskalakis et al. (2017), Ramli et al. (2019).

\subsection{Methodology}

Regression analysis was chosen to determine the relationship between endogenous and exogenous variables. More specifically, panel regression, the use of which is appropriate with respect to a large sample of companies and determinants that are the subject of this research. The use of panel regression and panels allows creating more dynamic model while monitoring company heterogeneity. However, a simple panel regression - the least squares method is insufficient for this research as the study period is relatively short and also requires stationary data, which would eliminate a number of financial series and the resulting models would not have to contain all the variables (usually determinants of external environment) (Průcha, 2014).

As reported by Jagannathan et al. (2002), the two-stage Generalized Method of Moments (GMM) eliminates shortcomings of other methods which can be used for business data analysis. At the same time, overall, this method was developed primarily for financial research. This method was first explained and given some foundation in a study by Arellano and Bond (1991). Subsequently, the model was developed and shaped in other studies.

The general attributes of this method are described in study of Roodman (2009): suitable for a large set of data, which, at the same time, may not include a long period of time; existence of a linear functional relationship; presence of a fixed individual effects; on the left side of equation, there is only one dependent variable depending, among other things, on its own lagged value; for a change, an independent variable does not have to be given exactly (which means that there may be a correlation between past and present errors); and finally autocorrelation and heteroskedasticity, which are not tested in any way within this method (for example unlike the least squares method), should not be across individual observations, but may be within them.

A significant positive effect of this method according to Ullah et al. (2018), the solution of the problem of endogeneity = correlation between the independent variable and the error term is. This method conceals certain elements regulating the sources of endogeneity, which are considered unobserved heterogeneity, simultaneity and dynamic endogeneity. These elements include, for example, the already mentioned lagged value of the dependent variable, which forms one of the independent variables on the right side of the equation. Furthermore, this author states that it is necessary to test the accuracy of the model with respect to the possible occurrence of autocorrelation and heteroskedasticity. There are a number of tests. This research uses the Sargan test. The results of this test specifically show the extent to which the model is able to provide almost the same results even if we slightly change its parameters. The model is built correctly if its final values are higher than 0.05 . The following equations capture the analyzed relationships between variables:

$$
\begin{aligned}
& Y_{i t}=\alpha_{0}+\beta_{1} * Y_{i t-1}+\beta_{2} * R O A_{i t}+ \\
& +\beta_{3} * L 2_{i t}+\beta_{4} * S A_{i t}+\beta_{5} * G D P_{i t}+ \\
& +\beta_{6} * I N F_{i t}+\beta_{6} * I R_{i t}+\varepsilon_{i t}
\end{aligned}
$$

where $Y_{i t}$ represents the endogenous variable DER/DER_L/DER_S, i.e., some form of indebtedness of the i-th number of companies in the given economy in the selected industry for the period 2009-2016. Exogenous variables denoting individual determinants are in the coefficients $\beta_{1}-\beta_{6}$. Among the exogenous variables is also $Y_{i t-1}$, which is generated automatically by the model and allows modeling the mechanism of partial adaptation in a dynamic model. This variable indicates the lagged value of the endogenous variable with one-year lag specifically as all data represent an annual frequency. The last variables are the symbols $\alpha$ and $\varepsilon$, which are also an automatic part of the model and represent the constant and the random component of the model. The random component contains all other determinants of the financial structure, which the research does not deal with and cannot be neglected.

\subsection{Characterization of Industry}

As for the industry, agriculture, forestry and fishery can be considered the neutral industry, in which companies produce vital products thus their development is not entirely linked to the development of the whole economy. However, 
this industry is affected by natural conditions especially climatic conditions. The development of these conditions affects this industry directly and indirectly. For example, agriculture, forestry and logging are directly affected by weather changes and, in recent years, by its atypical whims, which have a rather negative effect on agricultural production. For instance, in 2012, Europe was plagued by extreme frosts or in 2015, there was severe drought and heat. From the structure of the territory from the CIA database, it was found that Romania and Hungary have the largest amount of agricultural land $(60.7 \%$ and $58.9 \%$ of territory). By contrast, Slovenia has the least amount of agricultural land $(22.8 \%$ of territory). In all countries except Slovenia, arable land dominates, but in Slovenia it is permanent pasture.

It is well known in European countries that agriculture, forestry and fishery do not contribute significantly to GDP - in average $3.6 \%$. At the same time, the main products of this industry are very similar in selected economies: potatoes, wheat, vegetables, sugar beet, corn, fruits, hops, sunflower seeds, eggs, pigs, sheep, cattle, and poultry.

The structure of the territory from the CIA database also shows what percentage of the territory is occupied by forests. The largest area $(62.3 \%)$ can be found in Slovenia. As it comes to the composition of forests - coniferous forests predominate in Poland and the Czech Republic; broadleaf forests predominate in Romania, Bulgaria, Hungary and Slovakia. In the aforementioned Slovenia, it is fifty-fifty.

The last part of the industry is fishery. Last but not least, the structure of the territory from the CIA database contains the percentage of the territory occupied by water areas - on average it is around $2.4 \%$. Of course, there are fresh bodies of water in all countries, but salty ones are not a matter of course. The Czech Republic, Slovakia and Hungary are landlocked countries without access to any sea or ocean. Poland has access to the Baltic Sea, Romania and Bulgaria to the Black Sea and Slovenia to the Adriatic Sea. To compile information on the sub-industry, the World Bank database (fishing production statistics) was used, which contains the volume of aquatic species caught by a country for all commercial, industrial, recreational and subsistence purposes in tones. To bring an idea, how much the researched economies produce, the numbers of production volume were converted to percentage to show by how many percent those countries contribute to the European Union fisheries production. The Polish economy shows the largest share - 3.9\%. The remaining economies range from 0.03 to $0.4 \%$, which means that fishery is not a significant economic activity for given economies.

\subsection{Characterization of Economic Development in Selected Economies}

Following the characteristics of the industry, it is also appropriate to characterize the economic development in selected countries. Each of the economies has had its own specific development, but the world and Europe have been affected by several events. At the beginning of the period under review, the global financial crisis subsided, which turned into a global economic crisis. In Europe, this crisis was followed by a debt crisis associated mainly with the countries of southern Europe and Ireland. The latest event, the global slowdown in economic growth in 2013 was. Seven selected economies reacted differently to those events.

The Polish economy is the only economy having not been hit hard by any of these events, and has even grown in GDP throughout. Although it is true that in 2012 and 2013, the growth was lower (1.61 and $1.39 \%$ ) compared to the average growth before and after these years, which was over $3 \%$. Poland is also the only country in the European Union that did not undergo the recession during the crisis period 2009-2013 and its GDP grew by $2.9 \%$ year on year on average. The reason for this great development, the stimulus package after joining the European Union is, European subsidies, co-organization of the European Football Championship in 2012 (high public investment), the size and relative separateness of the economy. In times of crisis, the economy was supported by strong domestic demand.

Bulgaria is another economy that did not have major problems in crises. In 2009, GDP fell, unemployment and the government deficit increased. In 2012 and 2013, GDP grew, but at a very slow pace. However, despite these fluctuations, the economy functioned without major problems.

The Czech Republic emerged relatively well from the financial crisis, although GDP fell sharply in 2009, but the economy did not 
have major problems. The problems came only with the onset of the global slowdown, when GDP fell in 2012 and 2013 due to a decline in domestic demand and investment as well as foreign demand. Consumers' demand declined as household disposable income declined. Companies reduced investments with regard to fiscal restrictions in 2012 and the update of tax legislation in 2013. In the same period, exchange rate interventions were introduced by the Czech National Bank; these interventions remained ongoing from 2013 to 2017. A failure to meet the inflation target and deflation danger was the reason for doing so.

Slovakia was not significantly affected by the financial crisis either; however, in 2009, GDP fell by almost $6 \%$. The decline in foreign demand and in production was the reason of it, especially in the pro-export industries (mainly the automotive industry, which in this period accounted for one quarter of the Slovak GDP). In the following years, GDP grew, even in 2012/2013 although in these years, the increase was lower. The reason why Slovakia was not hit hard by the crisis can be found in both the long-term illiquid stock exchange and, above all, in the fixation of the Slovak koruna to the Euro as Slovakia entered the Euro area at the beginning of 2009 .

The next three economies were not so lucky and, unfortunately, the financial crisis hit them hard. Slovenia went through the same developments in the real estate and mortgage markets as the United States did, which triggered the crisis. Unfortunately, there was also a real estate bubble, which was associated with mortgage financing. From 2008 to 2014, the entire real estate market and prices fell. Following this crisis, Slovenia went straight to the banking crisis in 2013. This crisis had its origins in excessive risk-taking, poor management of state-owned banks and insufficient supervision. Unfortunately, most banks were state-owned. Despite these significant problems, Slovenia did not request international assistance and the economy stabilized in 2015 thanks to local government reforms.

Hungary was significantly influenced by the crisis due to poor government performance, high indebtedness and an export-oriented economy. Above that, the crisis had another impact here involving exchange rates and currencies; companies and ordinary citizens often were burdened by loans and mortgages in Euros or, more often, in Swiss francs. The crisis was also accompanied by a forint weakening, which significantly increased the indebtedness level of these entities. In 2008, in order to stabilize the economy, the government was forced to apply for an international loan, which it received in amount of almost 6.5 billion from the IMF, WB and the EU. Unfortunately, the subsequent growth did not last long as the Hungarian economy was also hit by a slowdown in 2012 and 2013.

The last economy considered, Romania is, which also had to apply for an international loan in 2009, which it received in the amount of 20 billion. This loan strengthened foreign exchange reserves and revitalized the credit market. The economy recovered and even grew as one of the few during 2012/13.

\subsection{The Amount and Composition of Liabilities and Capital Structure in Individual Economies}

Before analyzing the results of the regression analysis, it is important to analyze the dependent variable, i.e., indebtedness. In Tab. 2, we can see the average values for medium and large companies in terms of non-current liabilities (NCL), current liabilities (CL), debt, equity and debt-equity ratio.

Non-current liabilities include long term liabilities of the company, which consist of longterm financial debts (e.g., loans, credits, bonds), other long-term liabilities (trade debts, group companies, pension loans, etc), provisions (social security, taxes, etc) and deferred taxes. Current liabilities consist of loans (e.g., to credit institutions, part of long-term financial debts payable within the year, bonds, etc), debts to suppliers and contractors (trade creditors), and other current liabilities (pension, personnel costs, taxes, intragroup debts, accounts received in advance, etc). Debt is then the sum of the non-current and current liabilities. Equity includes capital and other shareholders funds.

We can see that the debt is not excessively high; the highest values (2.1) of the debt-equity ratio are reached by Romanian medium-sized companies. It is obvious that debts exceed equity twice. This may be caused by the fact that Romanian agriculture was still not as efficient as it was during the period under review. This industry was poorly technically equipped, unproductive and lacked finances. Liabilities' increase could be caused by e.g. subsidies of 
Tab. 2: The amount and composition of liabilities and capital structure

\begin{tabular}{l|c|c|c|c|c|c|c} 
& CZ & SK & PL & HU & SI & BG & RO \\
\hline NCL_medium & $56 \%$ & $27 \%$ & $53 \%$ & $35 \%$ & $40 \%$ & $39 \%$ & $46 \%$ \\
\hline NCL_large & $42 \%$ & $38 \%$ & $35 \%$ & $31 \%$ & $39 \%$ & $30 \%$ & $36 \%$ \\
\hline CL_medium & $44 \%$ & $73 \%$ & $47 \%$ & $65 \%$ & $60 \%$ & $61 \%$ & $54 \%$ \\
\hline CL_large & $58 \%$ & $62 \%$ & $65 \%$ & $69 \%$ & $61 \%$ & $70 \%$ & $64 \%$ \\
\hline Debt_medium & $41 \%$ & $53 \%$ & $43 \%$ & $36 \%$ & $57 \%$ & $45 \%$ & $68 \%$ \\
\hline Debt_large & $16 \%$ & $28 \%$ & $34 \%$ & $44 \%$ & $51 \%$ & $49 \%$ & $60 \%$ \\
\hline Equity_medium & $59 \%$ & $47 \%$ & $57 \%$ & $64 \%$ & $43 \%$ & $55 \%$ & $32 \%$ \\
\hline Equity_large & $84 \%$ & $72 \%$ & $66 \%$ & $56 \%$ & $49 \%$ & $51 \%$ & $40 \%$ \\
\hline Debt-equity ratio_medium & 0.70 & 1.10 & 0.76 & 0.59 & 1.31 & 0.82 & 2.10 \\
\hline Debt-equity ratio_large & 0.20 & 0.39 & 0.53 & 0.77 & 1.07 & 1.10 & 1.49 \\
\hline
\end{tabular}

Source: own based on the data from Orbis database

European funds or other investment incentives that the industry in Romania desperately needed. Slovak medium-sized companies, Slovenian companies and Bulgarian large companies are other ones, in which the debtequity ratio exceeded 1 . However, the values are not significantly high.

A review of the literature indicated what the structure of assets in agriculture should probably look like, from which the structure of liabilities derives. We see that only in the case of mediumsized Czech and Polish companies', long-term liabilities prevail and, in all cases, not significantly. The predominance of short-term liabilities in Czech agricultural companies was also revealed, for example, by Stehel et al. (2019). Liabilities arising from business relationships with suppliers are the main component in these short-term liabilities, on average.

\section{Research Results and Discussion}

Tab. 3 shows the resulting panel regression coefficients for medium-sized agricultural companies for the three forms of debt. It is clear that complete results for all economies and determinants are not available for any form of debt. Some economies were excluded due to non-compliance with the Sargan test. Its results are presented in the last column. The missing economies did not exceed value of 0.05 , so the models were not robust and had no significance. The remaining economies passed this test and in the last column, we see that the values exceed the given value.
As mentioned in the Methodology section, the GMM model contains an automatic variable - the lagged value of the dependent variable, the coefficients of which are captured in the first column. We see that most of these coefficients are statistically significant. The positive impact prevails, which means that if companies used debt financing in the previous period, they would likely use it in the following period thus they would increase the debt. On the other hand, the coefficients are so low that we cannot practically talk about any impact.

For profitability, all forms of indebtedness were expected to have a negative impact on the debt level. Such impact was met by Czech, Polish, Bulgarian and Romanian companies. These results were also confirmed in studies involving these economies by the following authors - Weill (2004), Nivorozhkin (2005), Prášilová (2012) also for agriculture, Mokhova and Zinecker (2013), Prędkiewicz and Prędkiewicz (2015), Růčková (2015b) for Polish companies. On the other hand, Růčková (2015a, 2015b) revealed a positive impact of profitability on the indebtedness level in Czech companies, but they were companies of the construction, manufacturing and energy industries. This was expected in Poland and Bulgaria because these economies prospered during the period under review and did not have major economic problems. The negative impact of profitability even matched the GDP growth rates in these countries being also negative indicating that companies preferred to 
use the equity over the debt financing in times of economic prosperity. Also, in the Czech Republic, the results of profitability and GDP correspond to each other. Czech companies were successful for most of the period due to favourable climatic conditions; although the development of the economy had a few fluctuations, this industry should not have been strongly influenced by the development of the economy. Slovenian companies were among the companies in which debts predominated over equity, the debt-equity ratio was on average 1.31 during the period under review. Moreover, within only three years, companies tried to reduce their debts but not significantly. In 2009 and 2011, companies reported the losses, on average. This is not surprising, as Slovenian agriculture is characterized by a large number of small-scale farms, which are low-productive. Slovenia received a number of subsidies from European funds to support rural development and agriculture. These resources were likely to be accounted for the majority of debt and therefore, debt would not decline with rising profits but rather the opposite. This positive impact is also confirmed by the results of a study by Mokhova and Zinecker (2013). On the contrary, Črnigoj and Mramor (2009) found a negative impact of profitability on the indebtedness level in Slovenian companies. Unfortunately, none of the studies can specify the industry. Romanian companies, as mentioned above, were on average the most indebted companies examined. The negative impact of profitability indicating a decline in debt with rising profits makes sense as the debtequity ratio fell from 2.21 to 2.01 during the period under review. Debt decreased mainly in 2011, 2014 and 2016, when the profits of these companies grew due to the good climatic conditions which was favourable to the industry. The positive impact in Hungary was in line with the positive coefficient for GDP growth. Given the economic development in Hungary after the financial crisis in $2008 / 2009$, it is clear that companies developed along with the economic environment taking possible indebtedness in a currency other than the national currency into account as in 2009 companies were most indebted for the whole period. The studies of Růčková (2015a, 2015b) came to the same conclusion, despite the fact they focused on other industries. On the contrary, there are several studies that have looked at Hungarian companies, but their results tend to have a negative impact of the profitability on debt levels. This study is, e.g., Mokhova and Zinecker (2013).

Our liquidity assumptions were met by Hungarian, Bulgarian and Slovenian companies; on the contrary, Polish and Czech companies did not fulfill the assumption. Unfortunately, as with the lagged values of indebtedness, the coefficients are also very low here, and therefore the effect of liquidity on the amount of indebtedness cannot be discussed. Unfortunately, many authors did not include liquidity in their research, and therefore, we can compare our results with only a few results of studies that dealt with our selected economies. Pinková (2012) and Aulová and Hlavsa (2013) are in conflict with our results, as they revealed a negative impact for Czech companies. The results of Aulová and Hlavsa (2013) are interesting because the authors also examined the agricultural industry. However, the authors performed the analysis for individual years and not for the whole period like we did, and therefore, there could be a difference. Their results reach similarly low values as ours. The Czech companies were also dealt with by Růčková (2015b); in her studies, the positive effect of liquidity on the indebtedness level was confirmed; however, the difference may be due to the focus on the manufacturing industry. At the same time, in this study, the author revealed a negative impact on Polish companies, which is again at odds with our results, but the difference may be due to a different industry. The latest study on the effects of liquidity was performed by Mateev et al. (2012). Unfortunately, the authors combined the selected economies (Bulgaria, the Czech Republic, Hungary, Romania, Poland, Slovakia) in one panel, so it is not possible to determine the impacts in individual countries. The authors found a positive impact on the level of longterm debt and a negative impact on the level of short-term debt.

Due to the fact that short-term liabilities predominated in the capital structure of agricultural companies and, at the same time, there was a large amount of inventories in the property structure, a negative impact was expected on total and short-term debt and a positive impact on long-term debt. Although medium-sized companies possess on average $55 \%$ of tangible assets available out of total 
assets, most liabilities are short-termed thus those tangible assets cannot be used as collateral. In the Tab. 3, we can see that the negative coefficients are related to all forms of debt. There are only two positive coefficients in the case of Czech and Polish companies in terms of total debt. This is due to the fact that these companies are dominated by long-term liabilities for which these assets can be used as collateral. In terms of total and short-term debt, for countries with a negative ratio, this is due to the fact that most liabilities from total are short-term. What is special about the results, the negative effects asset structure on longterm debt is. In the Slovenian, Hungarian and Romanian companies, almost all fixed assets are tangible; companies come from economies in which they are even bank-oriented systems. On the other hand, inventories account for $19 \%$ of Hungary's assets and $17 \%$ of Romania's total assets. In Slovenia it is only $9 \%$. Only the results of studies on agriculture or construction will be used to compare the results on the impact of the asset structure, as these sectors may have a large amount of stocks that do not serve as collateral for debt financing. A possible negative impact was found in the Aulová and Hlavsa (2013) studies, which dealt with Czech agricultural companies, Růčková (2015a) for Czech, Polish and Slovak construction companies. On the contrary, a positive effect was found in the studies by Prášilová (2012) for Czech agricultural companies and Růčková (2015a) for Hungarian construction companies. Sikveland and Zhang (2020) focused on Norwegian salmon aquaculture, confirming a positive impact on long-term and total debt, while confirming a negative impact on short-term debt. The difference in the results, with respect, can be given by the size of the samples - Prášilová (2012) examined only 49 companies, Aulová and Hlavsa (2013) examined 16,075 companies and our sample includes 10,644 companies.

The results of the GDP growth rate were not mentioned only for Romania. The positive coefficient for short-term debt does not fulfill the assumption; however, apart from the post-crisis years of 2009/2010, the Romanian economy was very successful, which was probably optimistic for companies even in the short-term period. Unfortunately, as it comes to the impact of GDP growth on the debt level, there is no study focusing on individual economies available to be compared with. Hanousek and Shamshur (2011) found a positive impact of this variable in a panel of countries that included the Czech Republic, Hungary, Poland and Slovakia. When dividing the sample of companies into listed and unlisted companies, a positive effect was found for unlisted companies and a negative effect for listed companies. This negative connection was also confirmed by Jõeveer (2013), who also examined a panel of countries in which we would find Bulgaria, the Czech Republic, Hungary, Poland, Romania, and Slovakia. If we look at the studies regardless of geographical affiliation, we get another six results for comparison. For Nepalese companies, Gajurel (2006) revealed a negative dependence between the variables for total and short-term debt and a positive dependence for long-term debt. The positive dependence was also confirmed by Yinusa et al. (2017) in the case of Nigerian companies. This result is slightly at odds with ours for Polish companies for long-term debt and for Romanian companies for short-term debt. Ramli et al. (2019) found a negative impact for Malaysian companies and a positive impact for Indonesian companies. The remaining authors again examined a panel composed of several countries. Cheng and Shiu (2007) revealed the negative impact of GDP on debt in a panel of 45 countries, so did Bokpin (2009) in a panel of 34 emerging markets and Yildrim et al. (2018) for Shari'ah compliant and non-compliant companies from the US, the UK, Canada, Japan, South Korea, Taiwan and India.

The inflation results meet the expected effects only for short-term debt of Slovak, Hungarian and Bulgarian companies and for long-term debt of Romanian companies. In Romania, this is justified by the development of the inflation rate, which averaged just under $3 \%$ during the period under review being thus the highest of the countries monitored. In 2009-2011, the inflation rate was even 5.5\%; this higher inflation could mean the advantage for cheaper debt. The same explanation can be applied in Hungary in terms of total debt, where the economy averaged $2.5 \%$ inflation. In the short term, there is a positive impact, given the possibility of hedging against higher inflation. For the remaining economies, the resulting links are difficult to explain as the remaining economies averaged $1.3 \%$ inflation and often deflated in 2014-2016. Given that the values 
range from one to minus one, which are not high values, a direct real impact of inflation on the debt level cannot be expected. The development of the inflation rate is reflected in agricultural products, which subsequently affect enterprises through the amount of profits, etc. As for the effect of GDP, there are no studies for individual economies to compare the results for the inflation rate with. Hanousek and Shamshur (2011) revealed a positive impact of inflation on the level of debt in a panel of Visegrád countries, while Jõeveer (2013) in a panel of six transition economies confirmed the negative impact of this variable. Only one study partially confirms our assumptions, namely Yinusa et al. (2017) found a negative impact on the longterm indebtedness of Nigerian companies, as we expected, and we confirmed this for Romanian companies. However, this author also found a negative impact on the amount of short-term debt. Gajurel (2006) revealed a negative impact for short-term and total debt, while it revealed a positive impact for long- term debt. Cheng and Shiu (2007), Öztekin (2015), Daskalakis et al. (2017), Bilgin (2019) also confirmed the negative impact of this variable in their research. In contrast, Ramli et al. (2019) revealed a positive impact of inflation on the indebtedness level in Malaysian and Indonesian companies.

The impact of interest rates is being met as expected for all companies except Bulgarian ones. As for the Bulgarian, Czech, Slovenian and Slovak companies, the interest rate in these countries was very low during the period under review, ranging from 1 to $0 \%$. This development suggests the possibility of cheaper loans, as the interest rate reflects the cost of debt. By contrast, rates were quite high in Poland, Hungary and Romania. In the last two economies, they even reached $7 \%$ and $8 \%$. Obviously, with the rising cost of debt, debt itself would decline. The interest rate is included in a much smaller number of studies than remaining macroeconomic factors. Antoniou et al. (2002) revealed a negative impact on German, British

\section{Tab. 3: GMM results for medium-sized companies}

\begin{tabular}{|c|c|c|c|c|c|c|c|}
\hline \multicolumn{8}{|c|}{ Total debt } \\
\hline & $\operatorname{DER}(-1)$ & ROA & L2 & SA & GDP & INF & IR \\
\hline $\mathrm{CZ}$ & $0.016^{a}$ & $-2.371^{a}$ & & $5.720^{\mathrm{a}}$ & $-32.237^{c}$ & $103.734^{c}$ & \\
\hline $\mathrm{PL}$ & $0.020^{c}$ & & $0.002^{b}$ & $3.582^{\mathrm{a}}$ & $-21.859^{a}$ & & $-508.139^{\circ}$ \\
\hline $\mathrm{HU}$ & $0.008^{a}$ & $1.493^{a}$ & & & & $30.966^{a}$ & \\
\hline$B G$ & $0.106^{a}$ & & $-0.002^{a}$ & $-1.527^{a}$ & $-24.827^{a}$ & $79.817^{b}$ & $103.894^{c}$ \\
\hline \multicolumn{8}{|c|}{ Long-term debt } \\
\hline $\mathrm{CZ}$ & $-0.029^{a}$ & & $0.008^{b}$ & & & $22.700^{\mathrm{a}}$ & $3.500^{\mathrm{b}}$ \\
\hline $\mathrm{PL}$ & & $-2.250^{\mathrm{a}}$ & & & $-21.167^{b}$ & $196.437^{c}$ & \\
\hline $\mathrm{HU}$ & $0.002^{\mathrm{a}}$ & & & $-3.634^{a}$ & $89.142^{\mathrm{a}}$ & & $-41.449^{a}$ \\
\hline SI & $-0.014^{a}$ & $25.696^{a}$ & $-0.236^{a}$ & $-34.784^{b}$ & & $102.494^{a}$ & $126.477^{a}$ \\
\hline RO & $0.004^{a}$ & & & $-95.133^{a}$ & & $-843.162^{a}$ & \\
\hline \multicolumn{8}{|c|}{ Short-term debt } \\
\hline SK & $-0.009^{a}$ & $0.725^{a}$ & & $-20.117^{a}$ & & $112.104^{\mathrm{b}}$ & $124.550^{\mathrm{a}}$ \\
\hline $\mathrm{PL}$ & $-0.141^{a}$ & & & $-3.105^{a}$ & $-5.511^{a}$ & & $-157.169^{a}$ \\
\hline $\mathrm{HU}$ & $0.003^{a}$ & & $-0.027^{b}$ & $-2.272^{b}$ & & $14.759^{a}$ & \\
\hline BG & & $-0.385^{a}$ & $-0.002^{a}$ & & $-20.969^{a}$ & $28.053^{a}$ & \\
\hline RO & & $-1.773^{c}$ & & $-68.380^{c}$ & $136.556^{b}$ & & $-644.178^{c}$ \\
\hline
\end{tabular}


and French companies. The same is true for Greek companies, as confirmed by Daskalakis et al. (2017). Ramli et al. (2019) found a negative impact for Malaysian companies, while a positive impact was found for Indonesian ones. Yinusa et al. (2017) found a negative impact on the short-term debt of Nigerian companies, while confirming a positive effect on long-term debt. Bokpin (2009) also has a positive impact.

Before moving on to the results of large companies, it is appropriate to make a brief recommendation for medium-sized companies on how they could respond to the results obtained. Overall, medium-sized companies are more sensitive to the determinants of capital structure, as such companies can afford a much lower level of indebtedness than large companies, as potential bankruptcy could occur much earlier. The results show a predominant negative impact of GDP, which means that companies are aware of their vulnerability, despite the fact that during the period under review, the economy more or less prospered, so they preferred to reduce their debt to prepare for worse times. Furthermore, companies should work with inflation expectations, as the results show that the positive effect may be due to inflation reducing the availability of funds, as companies pay much less in real terms than the declared rate. The research was carried out at a time of an average inflation rate of around $1.4 \%$ in the examined countries (except Poland and Romania). Today, the inflation rate is much higher, and therefore companies should monitor this variable much more, given the size and positivity of the coefficients and the higher usability of debt financing. At the same time, companies should monitor central banks' announcements of interest rate increases/ reductions that have had a significant impact on the choice of funding sources. Tab. 3 clearly shows that when interest rates are low, companies use more debt financing (positive coefficients), while in countries such as Poland, Romania and Hungary, interest rates were very high for a significant period of time, and therefore companies preferred their own funding sources within view of this vulnerability, as the high cost of debt financing could mean early bankruptcy.

Tab. 4 shows the resulting panel regression coefficients for large agricultural companies for three forms of debt. It is clear that, as with medium-sized companies, complete results are not available for all economies and determinants. The last column captures the results of the Sargan test. Economies not included in the table did not exceed 0.05 , the models were not robust and had no informative character.

As for the lagged value of the dependent variable, the negative impact prevails, which means that if companies used debt financing in the past, they would unlikely use it in the future and it would lead to a decline in debt. Again, the level of the coefficients is not high and even here, we cannot talk about the obvious effect of past indebtedness. However, there is one exception, for Polish companies in terms of total and short-term debt, where the coefficient is a single digit. This is a positive impact of past debt, which would increase future debt by 2 units. If we imagine, for example, 2 million under this number, this effect is already noticeable and relatively large.

The negative impact of profitability on the amount of debt was confirmed in Poland, Slovakia, Bulgaria and the Czech Republic. At the same time, this impact corresponds to the impact of the GDP growth rate, which also has a negative effect on these countries. These two effects mean that companies use their own sources of financing rather than debt financing in times of economic growth, when profits usually grow. This result is not surprising as basically all four countries economically developed without major fluctuations during the period under review; Bulgaria and Poland were doing even very well. These results were also confirmed in studies dealing with these economies provided by the following authors - Weill (2004), Nivorozhkin (2005), Prášilová (2012) also for agriculture, Mokhova and Zinecker (2013), Prędkiewicz and Prędkiewicz (2015), Růčková (2015b) for Polish companies. On the contrary, Růčková (2015a, 2015b) founded a positive impact of profitability on the indebtedness level in Czech companies, but they were companies of the construction, manufacturing and energy industries. The positive impact of profitability can be observed in Slovenian and Hungarian companies. Here, too, the GDP growth rate had a positive impact on the debt level. Although the industry should not have been affected by economic development, in Hungary this was possible because of the forint weakening during the financial crisis, which led to an increase in indebtedness as economic agents often borrowed money in Swiss francs or Euros. This 
result is very interesting due to the fact that if we compare the development of profit and the movement of the debt-equity ratio, only in 2010 and 2016, when profits fell, debts also fell. In the remaining years, the development of these variables went against each other, which would rather indicate a negative link. Even in 2015, profits fell by about $32 \%$, the debt-equity ratio rose from 73 to $95 \%$, which was a significant increase in debt. There are several studies that have looked at Hungarian companies, but their results tend to have a negative impact of the profitability on debt levels. These studies are: Mokhova and Zinecker (2013). On the contrary, the studies of Růčková (2015a, 2015b) came to the same conclusion, despite the fact that they focused on other industries. As for Slovenia, the development of profit and debt-equity ratio was relatively the same. We do not have to take the connection with the economy development into account as the coefficient is very low. A positive impact for Slovenian companies is also confirmed by the results of a study by Mokhova and Zinecker (2013). On the contrary, Črnigoj and Mramor (2009) found a negative impact of profitability on the indebtedness level in Slovenian companies. Unfortunately, none of the studies can specify an industry.

Liquidity assumptions were met by Slovak, Polish and Slovenian companies; on the contrary, Romanian companies did not meet our expectations. Unfortunately, the coefficients are not high here either, and therefore, it cannot be spoken about any effect of liquidity on the amount of debt. Unfortunately, many authors did not include liquidity in their research, and therefore, we can compare our results with only a few results of studies that dealt with economies selected by us. In this case, we can only compare the results for Polish and Slovak companies. Růčková (2015b) revealed a negative impact of liquidity on the indebtedness level in Polish and Slovak companies. Even though it is a manufacturing industry, the results are in line with ours. The effects of liquidity on the indebtedness level we can find in Mateev et al. (2012). Unfortunately, the authors combined the selected economies (Bulgaria, the Czech Republic, Hungary, Romania, Poland, Slovakia) into one panel, so it is not possible to determine the impacts in individual countries. The authors found a positive impact on the level of longterm debt and a negative impact on the level of short-term debt.
Also, in the capital structure of large companies, short-term liabilities prevailed much more than in the case of medium-sized companies. Large companies had inventories much less than the average, on average $12 \%$ of total assets. This could be caused by the fact that although agricultural companies predominated in the examined sample, companies of the forestry industry were also abundant, which, on the contrary, are characterized by tangible assets rather than inventories. However, even for large companies, the same assumptions remained regarding the impact of the asset structure. Tangible assets make up on average $56 \%$ of total assets, which is comparable to medium-sized companies, but Czech and Slovak companies even have 71 and $77 \%$ in assets. The negative coefficients for Poland, Hungary, Bulgaria and Romania are caused by the fact that companies in these countries, $61-70 \%$ of their liabilities are represented by short-term liabilities, for which tangible assets are not used as collateral. On the contrary, positive coefficients for Czech and Slovak companies make sense with regard to the amount of tangible assets in the property structure. Although these companies also have more short-term liabilities, tangible assets can be widely used as collateral for long-term liabilities. As in the case of mediumsized companies, only studies on agriculture or construction will be used to compare the results of large companies. As these sectors may have a large amount of stocks that do not serve as collateral for debt financing. A possible negative impact was found in the Aulová and Hlavsa (2013) studies, which dealt with Czech agricultural companies, Růčková (2015a) for Czech, Polish and Slovak construction companies. On the contrary, a positive effect was found in the studies of Prášilová (2012) for Czech agricultural companies and Růčková (2015a) for Hungarian construction companies. Sikveland and Zhang (2020) focused on Norwegian salmon aquaculture, confirming a positive impact on long-term and total debt, while confirming a negative impact on short-term debt. The difference in the results with respect can be given by the size of the samples: Prášilová (2012) examined only 49 companies, Aulová and Hlavsa (2013) examined 16,075 companies and our sample includes 10,644 companies.

Slovak, Hungarian, Bulgarian, Slovenian and Romanian companies have met expectations as inflation is concerned. As mentioned for 
medium-sized companies, in addition to the Hungarian economy, they had low inflation and sometimes deflation, which does not provide a clear explanation for why the inflation rate has a given impact. Year-by-year regressions would have to be made to explain the impact of the inflation rate on the indebtedness level of the economies concerned. The negative impact of inflation in Hungary occurred due to higher inflation rates in this country during the period under review, when the average inflation rate was around $2.5 \%$. At the same time, the inflation rate was around $4.7 \%$ for about half of the period under review, which may have brought the advantage of cheaper debt. There are no studies for individual economies to compare the results for the inflation rate. Hanousek and Shamshur (2011) revealed a positive impact of inflation on the debt level in a panel of Visegrád countries, while Jõeveer (2013) in a panel of six transition economies confirmed the negative impact of this variable. Only one study partially confirms our assumptions, namely Yinusa et al. (2017) found a negative impact on the long-term indebtedness in Nigerian companies, as we expected, and we confirmed this for Hungarian companies. However, this author also found a negative impact on the amount of shortterm debt as we founded in the case of Czech companies. Gajurel (2006) revealed a negative impact for short-term and total debt, and at the same time he revealed a positive impact for long-term debt. Cheng and Shiu (2007), Öztekin (2015), Daskalakis et al. (2017), Bilgin (2019) also confirmed the negative impact of this variable in their research. In contrast, Ramli et al. (2019) revealed a positive impact of inflation on the indebtedness level in Malaysian and Indonesian companies.

The impact of interest rates is being met by all economies. In the Czech Republic and Slovakia, interest rates were very low on average 0.34 and $0.51 \%$, with a maximum value of $1 \%$ at the beginning of the period under review in both economies. Slovakia even had a zero-interest rate in 2016 . Such low interest rates bring very low debt acquisition costs thus it is not surprising that the positive impact along. Low rates were also in Bulgaria so the negative impact is a big surprise. Hungary, Romania and Poland had relatively high interest rates during the period under review, with peaks of up to $8 \%$ for Romania. High rates carry high debt acquisition costs, which reduced debt as companies did not want to use debt financing. Unfortunately, the impact of the interest rate was not found in any study that included at least one of our selected economies, so we can only use studies that dealt with completely different economies for comparison. Antoniou et al. (2002) revealed a negative impact on German, British and French companies. The same is true for Greek companies, as confirmed by Daskalakis et al. (2017). Ramli et al. (2019) found a negative impact for Malaysian companies, while a positive impact was found for Indonesian ones. Yinusa et al. (2017) found a negative impact on the short-term debt of the level of debt of Nigerian companies, while confirmed a positive effect on long-term debt of these companies. Bokpin (2009) also found out a positive impact for a long-term debt.

Before moving on to the conclusions, it is appropriate to make a brief recommendation for large companies on how they could respond to the results obtained. Large companies can afford higher debt levels while having access to more financial sources than smaller companies. This is evidenced by far more diverse results than in the case of medium-sized companies. In Poland, the agricultural industry is one of the most important industries and almost all results show that, e.g., Polish companies strongly prefer their own resources despite the fact that this economy has not experienced an economic downturn for a long time. The only thing companies could focus on is monitoring inflation expectations that farmers have been able to take advantage of. During the period under review, the inflation rate in Poland was on average almost $3 \%$, which significantly reduces the real interest rate. The same results were obtained for Bulgaria, and therefore, the recommendation is also the same - focusing on inflation expectations, which have had a positive impact and helped to increase debt financing. There was nothing to prevent Bulgarian companies from indebtedness, as the economy prospered and did not suffer from any problems, but even so, companies preferred their own sources of financing. A similar recommendation can be used for Czech and Slovak companies, which also have negative signs for almost all coefficients, which indicate a preference of own financing sources. The only variable that has increased indebtedness is the interest rate, and therefore, companies should follow central banks' announcements of 
interest rate increases/decreases that have had a significant impact on the choice of funding sources. The Slovak and Czech economies were among the countries with very low interest rates, which was obviously used by agricultural companies, so interest rate announcements should be focused on. In Hungary, agriculture is one of the most important parts of the national economy. The economy has prospered since the middle of the period under review continuing in the following years. As a result, Hungarian companies were able to use more debt financing, which reflected the profitability. Higher average inflation rate reduced the value of current debt, which implies recommendations regarding inflation expectations. As it comes to Slovenian companies, they were very affected by the inflation rate. Average inflation rate was around $1 \%$, but even that was enough to reduce the real interest rate, which, given the level of rate (which was around zero), meant very cheap debt financing with very good impact on profitability.

\section{Conclusions}

This research focused on the financial structure and selected determinants that could affect it. The agriculture, forestry and fishing industry in seven selected economies of Central and Eastern Europe were the subject of the research, namely V4, Romania, Bulgaria and Slovenia. The financial structure was represented by the total, long-term and short-term indebtedness of the companies. As the specific determinants, profitability, liquidity, asset structure, GDP growth rate, inflation rate and the basic interest rate of the economy were used. A total of two research questions were tested on 10,664 companies, of which 9,771 were medium-sized and 873 large companies. The companies were analyzed for the period 2009 to 2016 using the Generalized Method of Moments. The aim of the research was to analyze the impact of selected determinants on the financial structure of seven selected economies belonging to the industry of agriculture, forestry and fishing. With regard to the formulated aim and literature overview, two

\section{Tab. 4: GMM for large and very large companies}

\begin{tabular}{|c|c|c|c|c|c|c|c|}
\hline \multicolumn{8}{|c|}{ Total debt } \\
\hline & DER(-1) & ROA & $\mathbf{L 2}$ & SA & GDP & INF & IR \\
\hline SK & & & $-0.315^{a}$ & $25.927^{a}$ & & $-557.025^{b}$ & $125.592^{c}$ \\
\hline $\mathrm{PL}$ & $2.046^{b}$ & $-30.784^{a}$ & & $-81.911^{b}$ & & $325.220^{\mathrm{a}}$ & \\
\hline $\mathrm{HU}$ & $-0.370^{a}$ & $2.898^{a}$ & & & $331.008^{a}$ & & $-176.022^{a}$ \\
\hline SI & & & & $-3.380^{b}$ & $0.672^{\mathrm{a}}$ & & \\
\hline \multicolumn{8}{|c|}{ Long-term debt } \\
\hline $\mathrm{CZ}$ & $-0.082^{a}$ & & & $1.782^{\mathrm{b}}$ & & $0.578^{c}$ & $5.362^{b}$ \\
\hline SK & & $-10.254^{b}$ & $0.014^{a}$ & & $-347.718^{a}$ & & $4.864^{a}$ \\
\hline $\mathrm{HU}$ & $-0.406^{a}$ & & & $-7.710^{a}$ & & $-415.431^{a}$ & \\
\hline BG & $-0.317^{b}$ & $-0.432^{a}$ & & & $-82.639^{a}$ & & \\
\hline RO & & & $0.002^{\mathrm{a}}$ & $-53.024^{a}$ & & & $-44.720^{a}$ \\
\hline \multicolumn{8}{|c|}{ Short-term debt } \\
\hline $\mathrm{CZ}$ & & $-1.368^{b}$ & & $1.671^{c}$ & $-2.676^{a}$ & $-6.022^{a}$ & \\
\hline $\mathrm{PL}$ & $2.329^{c}$ & & $-0.107^{a}$ & & $-396.134^{a}$ & & $-476.050^{c}$ \\
\hline SI & $0.481^{a}$ & $9.948^{\mathrm{a}}$ & $-0.090^{a}$ & & & $15.104^{b}$ & \\
\hline BG & $-0.504^{a}$ & & & $-0.228^{a}$ & & $59.289^{a}$ & $-167.214^{a}$ \\
\hline
\end{tabular}


research questions were formulated, answers to which were to be found within the research:

1. Are there differences in impact over different maturities of use of the funding sources used?

2. Does the price of financial external sources affect the use of them?

Within the research, partial aims were set - to find differences between the impact of determinants on the financial structure of medium companies and large companies. An analysis of the financial structure was also linked to this partial aim. This analysis showed that short-term liabilities predominate in the capital structure regardless of the company size. For large companies, the predominance of shortterm liabilities was higher than for medium-sized companies. At the same time, large companies were, on average, less indebted than mediumsized companies. Regarding the asset structure, depending on the industry, inventories should be more represented, as agriculturally oriented companies, which are characterized by a large amount of inventories, clearly dominate in almost all countries. Inventories of mediumsized companies accounted for on average $17 \%$ of total assets, for large companies this ratio was lower, only $12 \%$.

As for the impact of individual determinants, both internal and non-corporate factors had an impact on the debt level. However, the factors of the external environment - economic development, the inflation rate and the basic interest rate had a stronger impact. A total of seven factors were examined, the results of which are presented below.

The first variable, the annual lagged value of the debt itself was. Regardless of company size, the impact was very small, except for large Polish companies, where this impact was already in single digits of positive value. The positive impact for these companies means that if they used debt financing in the previous period, they would use it in the following period, which would increase the debt even more. In a more detailed analysis of the indebtedness of Polish large companies, this was indeed the case for almost the entire period under review. From 2009 to 2015, debt increased from PLN 3.8 billion to PLN 9.1 billion. In 2016, debt decreased to the value of PLN 8.2 billion. Due to the positive coefficient, it could be expected that debt would grow in the coming years, but given the current pandemic, it is not possible to plan the future development using previous data and impacts. The remaining impacts were very low, however, for medium-sized companies, an indication of a positive impact prevailed, while for large companies, an indication of a negative impact prevailed.

As for the impact of profitability, there was positive and negative impact seen on both types of companies; for both types of companies, the negative impacts slightly outweigh the positive ones. The positive impact means that if companies' profits grew, they avoided the risk of bankruptcy and were attractive to creditors. At the same time, lenders would offer them more debt financing options than usual. On the contrary, the negative impact means that in times of growing profits, companies preferred to use these resources to finance their business activities. Simultaneously, the impact of profitability in specific countries was often associated with the impact of development in GDP growth. Very often these effects are the same. When comparing countries regardless of companies' size, we can say that the negative impact was seen most often in the Czech Republic, Poland, Bulgaria and Slovakia. These economies developed without major economic difficulties during the period under review thus growing profits in a period of economic peace and prosperity led companies to use own sources of financing not to be overburdened in times of worse economic condition. In the future, it can be expected that if there is a relationship between profitability and economic development, the profitability coefficients are likely to have the same sign as the economic development coefficients. Given that the industry should be neutral, there will probably be no higher fluctuations in profitability due to the pandemic.

Regardless of the company size, the impact of liquidity was rather negative and, at the same time, very low thus we cannot talk about any influence at all. Rather, this indicates the direction, in which debt would be affected if liquidity had a more significant impact. A negative indication means that the more liquid assets a company has, the more its debt would decrease, as high liquidity can lead to insufficient investment activities and therefore, no debt financing would be needed.

The amount of tangible assets had a predominantly negative impact on debt level. For medium-sized companies, this impact was 
slightly more pronounced. A rather positive influence was usually expected. However, given that the sample examined was dominated by agricultural companies, a negative influence could also be expected with regard to the possible large amount of stocks. The negative impact of this variable on the indebtedness level means that the more tangible assets companies have that can be used as collateral, the more indebtedness would decrease as these assets cannot be used to hedge short-term liabilities, of which these companies have many. Mediumsized companies had on average $58 \%$ of liabilities in the form of short-term liabilities and large companies even $64 \%$. Of course, certain assets could also be used to secure short-term loans, but, e.g., inventories or semi-finished products in a selected industry are perishable relatively quickly and do not have a durability of even a few months.

The agricultural, forestry and fishing industry can theoretically be considered neutral, as this industry produce vital products and their development is thus not entirely related to the development of the whole economy, but rather to the climatic conditions that significantly affect the industry. Unfortunately, the results of the panel regression do not completely correspond to this statement, because in terms of the strength of the impact, the determinants of the external environment have a more significant impact on the indebtedness level than the internal one.

The development of the GDP growth rate had a rather negative impact, and this impact was more pronounced for large companies. This means that companies e.g. use their financing sources more in the period of economic growth, which is obvious, as their profits usually grow during such a period and from the point of view of capital structure, it would be appropriate to reduce debt, which could burden companies in times of crisis. Most of the examined economies did not undergo major fluctuations during the given period, and despite occasionally significant problems, at least half of the examined period, the economies were stabilized. With regard to economic development, the negative impact has its justification, as there is a link to the already mentioned impact of profitability. The negative impact of GDP is often associated with the negative impact of profitability, which is closely related as corporate profits usually grow in times of economic boom. Companies (which are not preparing very expensive investments, for which they would probably have to use a debt financing) should think about the future development of the economy, which always slows down after some time and even, for example, fall into recession. Given this, it would be appropriate to reduce debt in the case of increasing profitability; otherwise, it could even jeopardize the existence of society after the crisis. Although the results show that companies reduced their indebtedness during the period under review, the opposite is true. In the yearon-year analysis of total indebtedness, the indebtedness of Czech, Polish, Bulgarian and Romanian companies, regardless of their size, increased during the period under review and sometimes quite significantly. The indebtedness of Hungarian companies also increased, however, the coefficients for this economy was positive and an increase was expected. The only result that met the expectations of a decline in debt can be seen in Slovak mediumsized companies, where debt fell on average.

Considering the impact of the inflation rate, the positive impact on debt levels dominates for medium-sized companies (excluding Romanian companies), while for large companies, the impacts were half and half. Different impacts could be seen in Czech, Slovak and Hungarian companies, which was interesting considering that they are the same economies, just the companies were divided by the size. In the case of Polish, Slovenian and Bulgarian companies, a positive impact is observed for both types of companies. Most economies, with the exception of Romania and Hungary, had very low inflation rates, and sometimes even economies fell into deflation. The positive impact is very interesting. The development of the inflation rate lasted for several consecutive years and lenders were able to lend more funds, but they still could not be sure that the inflation rate would not jump by a few percentage points over a period of time for unpredictable reasons.

The impact of interest rates was more or less fulfilled according to the distribution of economic development. The results are basically in line with the development of interest rates. In Poland, Hungary and Romania, rates were quite high (around $4 \%$ on average, with peaks even around $8 \%$ ), and it was in these countries, regardless of companies' size, that the interest rate had a negative impact on debt levels. The impact was expected 
as a higher interest rate means higher debt acquisition costs. Conversely, in the remaining economies, interest rates had a positive impact on debt levels. In these economies, interest rates were very low, sometimes zero, which is attractive in terms of the debt cost. The only exceptions, Bulgarian large companies are, in which a negative impact is seen. The direction of the impact was very unexpected, as Bulgaria was one of the economies with the lowest interest rates during the period under review - on average $0.13 \%$ and a maximum $0.55 \%$. However, interest rates in all economies fell sharply during the period under review, sometimes to zero. Therefore, if this trend would continue, we can expect an increase in debt in all economies, including Romania, Poland and Hungary, given this variable.

Acknowledgments: This article was supported by SGS/16/2020 "Influence of selected internal and macroeconomic determinants on financial structure of companies in selected countries of Central and Eastern Europe."

\section{References}

Acedo-Ramírez, M. A., \& Ruiz-Cabestre, F. J. (2014). Determinants of Capital Structure: United Kingdom Versus Continental European Countries. Journal of International Financial Management \& Accounting, 25(3), 237-270. https://doi.org/10.1111/jifm.12020

Arellano, M., \& Bond, S. (1991). Some Tests of Specification for Panel Data: Monte Carlo Evidence and an Application to Employment Equations. The Review of Economic Studies, 58(2), 277-297. https://doi. org/10.2307/2297968

Aulová, R., \& Hlavsa, T. (2013). Capital structure of agricultural businesses and its determinants. Agris On-line Papers in Economics and Informatics, 5(2), 23-36. https://doi.org/10.22004/ag.econ.152688

Bilgin, R. (2019). Relative Importance of Country and Firm-specific Determinants of Capital Structure: A Multilevel Approach. Prague Economic Papers, 28(5), 499-515. https://doi.org/10.18267/j.pep.700

Bokpin, G. A. (2009). Macroeconomic development and capital structure decision of firms: Evidence from emerging market economies. Studies in Economics and Finance, 26(2), 129-142. https://doi. org/10.1108/10867370910963055
Bradley, M., Jarrell, G. A., \& Kim, E. H. (1984). On the Existence of an Optimal Capital Structure: Theory and Evidence. The Journal of Finance, 39(3), 857-878. https://doi. org $/ 10.2307 / 2327950$

Brealey, R. A., Myers, S. C., \& Allen, F. (2011). Principles of Corporate Finance (10th ed.). New York, NY: McGraw-Hill.

Cheng, S. R., \& Shiu, C. Y. (2007). Investor protection and capital structure: International evidence. Journal of Multinational Financial Management, 17(1), 30-44. https://doi. org/10.1016/j.mulfin.2006.03.002

Črnigoj, M., \& Mramor, D. (2009). Determinants of Capital Structure in Emerging European Economies: Evidence from Slovenian Firms. Emerging Markets Finance \& Trade, 45(1), 72-89. https://doi.org/10.2753/ REE1540-496X450105

Daskalakis, N., Balios, D., \& Dalla, V. (2017). The behaviour of SMEs' capital structure determinants in different macroeconomic states. Journal of Corporate Finance, 46, 248-260. https://doi.org/10.1016/j.jcorpfin.2017.07.005

Gajurel, D. P. (2006). Macroeconomic influences on corporate capital structure. SSRN Journal. https://doi.org/10.2139/ssrn.899049

Hang, M., Geyer-Klingeberg, J., Rathgeber, A. W., \& Stöckl, S. (2018). Measurement matters - A meta-study of the determinants of corporate capital structure. The Quarterly Review of Economics and Finance, 68, 211-225. https://doi.org/10.1016/j.qref.2017.11.011

Hanousek, J., \& Shamshur, A. (2011). A stubborn persistence: Is the stability of leverage ratios determined by the stability of the economy? Journal of Corporate Finance, 17(5), 1360-1376. https://doi.org/10.1016/j. jcorpfin.2011.07.004

Hernádi, P., \& Ormos, M. (2010). Capital structure and its choice in Central and Eastern Europe. Acta Oeconomica, 62(2), 229-263. https://doi.org/10.1556/aoecon.62.2012.2.5

Jagannathan, R., Skoulakis, G., \& Wang, Z. (2002). Generalized Method of Moments: Applications in Finance. Journal of Business and Economic Statistics, 20(4), 470-481. https://doi.org/10.1198/073500102288618612

Jin, X. (2021). Corporate tax aggressiveness and capital structure decisions: Evidence from China. International Review of Economics and Finance, 75, 94-111. https://doi.org/10.1016/j. iref.2021.04.008 
Jõeveer, K. (2013). Firm, country and macroeconomic determinants of capital structure: Evidence from transition economies. Journal of Comparative Economics, 41(1), 294-308. https://doi.org/10.1016/j.jce.2012.05.001

Klapper, L. F., Sarria-Allende, V., \& Sulla, V. (2002). Small- and Medium-Size Enterprise Financing in Eastern Europe (Policy Research Working Paper No. 2933). Washington, DC: World Bank. https://doi.org/10.1596/18139450-2933

Lambrinoudakis, C., Skiadopoulos, G., \& Gkionis, K. (2019). Capital structure and financial flexibility: Expectations of future shocks. Journal of Banking and Finance, 104, 1-18. https://doi. org/10.1016/j.jbankfin.2019.03.016

Lipson, M. L., \& Mortal, S. (2009). Liquidity and capital structure. Journal of Financial Markets, 12(4), 611-644. https://doi. org/10.1016/j.finmar.2009.04.002

Lourenço, A. M., \& Oliveira, E. C. (2017). Determinants of debt: Empirical evidence on firms in the district of Santarém in Portugal. Contaduría y Administración, 62(2), 625-643. https://doi.org/10.1016/j.cya.2016.06.010

Mateev, M., Poutziouris, P., \& Ivanov, K.(2013). On the determinants of SME capital structure in Central and Eastern Europe: A dynamic panel analysis. Research in International Business and Finance, 27(1), 2851. https://doi.org/10.1016/j.ribaf.2012.05.002

Modigliani, F., \& Miller, M. H. (1958). The Cost of Capital, Corporation Finance and the Theory of Investment. American Economic Association, 48(3), 261-297.

Modigliani, F., \& Miller, M. H. (1963). Corporate Income Taxes and the Cost of Capital: A Correction. American Economic Review, 53(3), 433-443.

Mokhova, N., \& Zinecker, M. (2013). The determinants of capital structure: The evidence from the European Union. Acta Universitatis Agriculturae et Silviculturae Mendelianae Brunensis, 61(7), 2533-2546. https://doi. org/10.11118/actaun201361072533

Moradi, A., \& Paulet, E. (2019). The firmspecific determinants of capital structure - An empirical analysis of firms before and during the Euro Crisis. Research in International Business and Finance, 47, 150-161. https:// doi.org/10.1016/j.ribaf.2018.07.007

Myers, S. C. (1984). The Capital Structure Puzzle. Journal of Finance, 39(3), 575-592. https://doi.org/10.2307/2327916
Myers, S. C. (2001). Capital Structure. The Journal of Economic Perspectives, 15(2), 81-102.

Nivorozhkin, E. (2005). Financing choices of firms in EU accession countries. Emerging Markets Review, 6(2), 138-169. https://doi. org/10.1016/j.ememar.2004.10.002

Orlova, S., Harper, J. T., \& Sun, Li. (2020). Determinants of capital structure complexity. Journal of Economics and Business, 110, 105905. https://doi.org/10.1016/j. jeconbus.2020.105905

Öztekin, Ö. (2015). Capital Structure Decisions around the World: Which Factors Are Reliably Important? The Journal of Financial and Quantitative Analysis, 50(3), 301-323. https://doi.org/10.1017/S0022109014000660

Pinková, P. (2012). Determinants of capital structure: Evidence from the Czech automotive industry. Acta Universitatis Agriculturae et Silviculturae Mendelianae Brunensis, 60(7), 217-224. https://doi.org/10.11118/ actaun201260070217

Prášilová,P. (2012). Determinantykapitálové struktury českých podniků [Determinants of the capital structure of Czech companies]. E\&M Economics and management, 15(1), 89-104.

Prędkiewicz, K., \& Prędkiewicz, P. (2015). Chosen determinants of capital structure in small and medium-sized enterprises - Evidence from Poland. Finanse, Rynki Finansowe, Ubezpieczenia, 74(2), 331-340.

Průcha, I. R. (2014). Instrumental Variables/ Method of Moments Estimation. In M. Fisher, \& P. Nijkamp (Eds.), Handbook of Regional Science (pp. 1597-1617). Heidelberg: Springer. https://doi.org/10.1007/978-3-642-23430-9_90

Ramli, N. A., Latan, H., \& Solovida, G. T. (2019). Determinants of capital structure and firm financial performance - APLSSEM approach: Evidence from Malaysia and Indonesia. The Quarterly Review of Economics and Finance, 71, 148-160. https://doi. org/10.1016/j.qref.2018.07.001

Roodman, D. (2009). How to Do Xtabond2: An Introduction to Difference and System GMM in Stata. The Stata Journal, 9(1), 86-136. https://doi.org/10.1177/1536867X0900900106

Růčková, P. (2015a). Vliv podílu dlouhodobého majetku a rentability na využití cizích zdrojů financování firem $v$ odvětví stavebnictví v zemích V4 [The impact of the share of fixed assets and profitability on the use of external sources of financing for companies 


\section{Business Administration and Management}

in the construction sector in the V4 countries]. Acta academica karviniensia, 15(2), 122-135. https://doi.org/10.25142/aak.2015.023

Růčková, P. (2015b). Vliv likvidity a rentability na využití zdrojů financování ve zpracovatelských podnicích $\mathrm{v}$ zemích V4. Acta academica karviniensia, 15(3), 69-79. https://doi.org/10.25142/aak.2015.032

Růčková, P., \& Stavárek, D. (2020). Are there differences in the use of debt capital in enterprises of different size? International Journal of Monetary Economics and Finance, 13(2), 163-176. https://doi.org/10.1504/ IJMEF.2020.107698

Sikveland, M., \& Zhang, D. (2020). Determinants of capital structure in the Norwegian salmon aquaculture industry. Marine Policy, 119, 104061. https://doi.org/10.1016/j. marpol.2020.104061

Stehel, V., Horák, J., \& Vochozka, M. (2019). Prediction of Institutional Sector Development and Analysis of Enterprises Active in Agriculture. E\&M Economics and Management, 22(4), 103118. https://doi.org/10.15240/tul/001/2019-4-007
Ullah, S., Akhtar, P., \& Zaefarian, G. (2018). Dealing with Endogeneity Bias: The Generalized Methods of Moments (GMM) for panel data. Industrial Marketing Management, 71, 69-78. https://doi.org/10.1016/j. indmarman.2017.11.010

Touil, M., \& Mamoghli, C. (2020). Institutional environment and determinants of adjustment speed to the target capital structure in the MENA region. Borsa Istanbul Review, 20(2), 121-143. https://doi.org/10.1016/j. bir.2019.12.003

Weill, L. (2004). What Determines Leverage in Transition Countries? Czech Journal of Economics and Finance, 54(5-6), 234-242.

Yildirim, R., Masih, M., \& Bacha, O. I. (2018). Determinants of capital structure: evidence from Shari'ah compliant and non-compliant firms. Pacific-Basin Finance Journal, 51, 198-219. https://doi.org/10.1016/j.pacfin.2018.06.008

Yinusa, O. G., Alimi, O. Y., \& Ilo, B. M. (2017). Macroeconomic determinants of capital structure of firms: Evidence from Nigeria. Journal of Knowledge Globalization, 9(2), 1-21. 